\title{
Climatic Envelope as an Urban Planning Tool to Configure Urban Fabric of Guwahati City to Support Daylight and Natural Ventilation
}

\author{
Amal Barman, Madhumita Roy, Arpan Dasgupta
}

\begin{abstract}
Over the last decade, as a result of rapid urban growth and increasing human population, Guwahati city is witnessing multilayered transformation owing to socio-economic, geo-political and technological issues. This constant increase of built form is resulting haphazard urban growth pattern in down town city areas sacrificing the access to daylight and solar radiation inside residential buildings. Even though the development pattern of Guwahati is controlled by established GMDA building bye-laws; these building regulations and guidelines are unable to control the organic growth of the city since there is no climate-sensitive approach available in the existing GMDA bye-laws. This paper aims to discuss the likelihood of constructing a composite climatic envelope by using daylight spacing angle and solar elevation angle techniques within the residential zone of Guwahati city. This paper also analyses how climatic envelope technique helps to establish an efficient height-to-width $(\mathrm{H} / \mathrm{W})$ ratio in spatial arrangement of residential neighbourhood and ensures a higher levels of daylight factor (DF), permits solar access to the neighboring buildings and also enables better ventilation rate inside every rooms of residential buildings. This paper analyses further to discuss about the performance of natural ventilation inside building envelope and reviews the common energy code of openable window to floor area $\left(W F R_{o p}\right.$ ) ratio in urban residential buildings. During this study, an existing urban spatial arrangement of residential neighbourhood under GMDA jurisdiction is studied, discussed and analysed. Results of this study, plotting $\mathrm{H} / \mathrm{W}$ ratio against average daylight factor and ventilation rate can be used as a preliminary urban design tool to configure the urban fabric especially within the residential zone of GMDA area.

Keywords: Climatic envelope, solar envelope, Daylight Factor, $\mathrm{H} / \mathrm{W}$ ratio, Natural ventilation
\end{abstract}

\section{INTRODUCTION}

Guwahati is the largest city of Northeast India with a distinctive urban fabric of uneven plains, urban wetlands, and panoramic hilly terrains. In recent years, with increasing population pressure and constant demands for quantum of built forms, the town is rapidly sacrificing existing green cover and water bodies. This is often triggering microclimate

Manuscript received on January 28, 2021.

Revised Manuscript received on February 04, 2021.

Manuscript published on February 28, 2021

* Correspondence Author

Amal Barman*, Department of Architecture, Jadavpur University, Kolkata, India. Email Id : am_barman@hotmail.com

Dr. Madhumita Roy, Department of Architecture, Jadavpur University, Kolkata, India. Email Id : mroy@arch.jdvu.ac.in

Dr. Arpan Dasgupta, Amity school of Architecture and Planning, Amity University, Kolkata, India. Email Id : adgupta@kol.amity.edu

(c) The Authors. Published by Blue Eyes Intelligence Engineering and Sciences Publication (BEIESP). This is an open access article under the CC BY-NC-ND license (http://creativecommons.org/licenses/by-nc-nd/4.0/)

changes because of a gentle increase of surface air temperature. This significant urban growth is controlled by prevailing urban codes and building construction bye-laws of Guwahati Metropolitan Development Authority (GMDA). But these development regulations don't seem to be adequate enough to manage the organic growth of the town since climate conscious energy efficient principles aren't properly included and followed in urban codes and GMDA building bye-laws. Introduction of energy efficient principles in GMDA building construction bye-laws will streamline the present haphazard pattern of development and help to configure urban fabric through climatic envelope technique to support natural ventilation and day lighting especially in residential buildings of Guwahati in the near future. Meanwhile, Guwahati experiences an average daytime temperature of $29^{\circ}$ to $34^{\circ}$ Celsius and high relative humidity of $65 \%$ to $95 \%$ in summer [3]. The high relative humidity causes the indoor thermal discomfort in summer months. This uncomfortable situation ends up in the utilisation of air-conditioner as compulsory alternative in almost every household to regulate the room temperature to the ideal level [3]. Active AC ventilation results high energy consumption in residential buildings and GHG emission from AC system escalates outdoor discomfort condition increasing surface air temperature. This growing crisis in down town Guwahati ends up in a requirement for passive cooling strategies for indoor climate modification. As a green initiative, effective use of natural ventilation is often an appropriate alternative to enhance outdoor overheating and indoor climate modification [3]. Optimum use of natural ventilation can reduce indoor temperature up to a good extent and daylight access can increase illumination level inside building to minimise the energy consumption. This paper discusses the development of climatic envelope analysing the available daylight and solar entrée in residential buildings of Guwahati city. Daylight envelope could be a proven technique to shape and keeping spaces between buildings to make sure adequate daylight inside building and solar envelope technique can ensure solar access to the road and adjacent buildings. Climatic envelope may be a combination of daylight and solar technique that ensures access of adequate daylight and radiation inside every building. It maintains an efficient $\mathrm{H} / \mathrm{W}$ ratio that makes wind passage inside urban spatial arrangement of local neighbourhood settlement and increase ventilation rate inside the urban residential building. This study discusses to establish an effective $\mathrm{H} / \mathrm{W}$ ratio of the urban canyon geometry

to confirm average daylight factor and adequate ventilation rate in urban residential buildings of Guwahati.

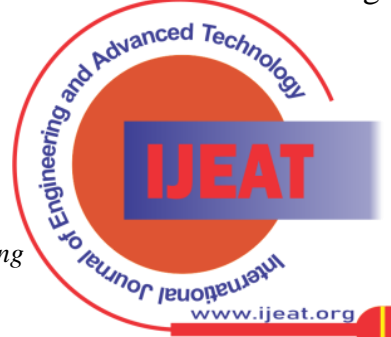




\section{Climatic Envelope as an Urban Planning Tool to Configure Urban Fabric of Guwahati City to Support Daylight and Natural Ventilation}

\section{CLIMATIC ENVELOPE CRITERIA}

\section{A. Daylight access}

Daylight access is often a primary necessity for the utilisation of daylight in buildings [2]. Zoning laws, the necessity of setbacks and height restriction in urban areas, are used to address for the worth of access to light and air [2]. With increasing height of building and density reduces the sunlight levels towards the road [2]. The amount of accessible daylight in buildings is suffering from various factors such as latitude, climate, obstructions and reflectivity of the adjacent surfaces.

\section{B. Daylight factor}

The daylight factor may be a quite common and simple method utilised to evaluate the quality of daylight in a very room of a building under an overcast sky condition. The higher the DF, the more is that the accessibility of natural light. The daylight factor is that the proportion of the illumination level inside a structure to the illumination level outside the structure and is expressed as:

$\mathrm{DF}=(\mathrm{Ei} / \mathrm{Eo}) \times 100 \%$

Ei - Daylight Illuminance at a unit area on the indoor working plane.

Overcast sky,

Eo - Simultaneous daylight Illuminance on a horizontal plane from an unobstructed hemisphere of sunshine.

Availability of daylight in buildings greatly depends on various aspects like the orientation of the building, its form, the position of the opening and kind of windows, zoning regulations, and therefore the quality of the inside material, colour and use. Table: 1 shows the minimum daylight factor requirement for visual comfort in different rooms of residential building.

Table:1 Recommended DF and illumination level in residential building [6]

\begin{tabular}{|l|l|l|}
\hline Type of space & Daylight factor (\%) & Illumination (lux) \\
\hline Study room & 1.90 & $200-500$ \\
\hline bedroom & 0.625 & $30-100$ \\
\hline kitchens & 2.50 & $300-750$ \\
\hline living room & 0.625 & $50-150$ \\
\hline Corridors, toilet & 0.313 & $50-150$ \\
\hline Dining room & 0.625 & $50-200$ \\
\hline
\end{tabular}

\section{Daylight Envelope}

The daylight envelope is the utmost developable volume that may be constructed in an exceedingly specific site while protecting daylight access to neighbouring buildings [2]. It offers prescriptive development control [2]. As a development technique, the daylight envelope tends to create street-oriented buildings with more ground coverage, and when the positioning of the site is fully developed, stepped up building forms. In highly dense urban situations, as road wall height increases subsequently daylight levels decreases. Daylight available to rooms facing the road depends on factors like the ratio of building height to the width of the road (H/W ratio), the reflectivity of the outside walls, and quantity of the glazing surfaces. Elevated street walls block more view of the sky from windows. So, windows in lower rooms are mostly illuminated by reflected light. Higher reflectivity of wall increases light level near the road. Table: 2 shows the specified DF of $26.11^{0}$ north latitude of Guwahati.

Table: 2 Daylight Factor, $\mathrm{H} / \mathrm{W}$ ratio and Min. spacing angle [5]

\begin{tabular}{|l|l|l|l|l|}
\hline Latitude & Require & $\mathrm{H} / \mathrm{W}$ & Min. spacing angle & Remarks \\
\hline
\end{tabular}

The amount of sunlight that reaches a window is primarily determined by the sky exposure angle (Fig:1). The required sky exposure angle to recommend a desired level of daylight at the building facade generates the sky exposure plane. A regulating sky exposure angle is commonly employed in urban development rules to work out the street wall height.

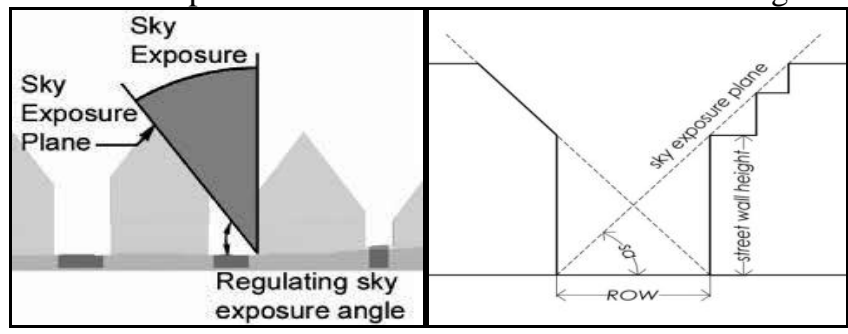

Fig: 1 sky exposure angle and sky exposure plane [2] When Daylight Access Rule is applied to an urban pattern of blocks and streets, a development envelope may be generated to regulate the limit of building boundaries so lower neighbouring building floors may also get sufficient daylight. This Daylight Access Rule is effectively utilised to work out a maximum $\mathrm{H} / \mathrm{W}$ ratio for a given DF goal. When road width is fixed, maximum facade height will be calculated and a Sky Exposure Plane is defined by drawing a line from the other side of the road or ROW at ground level through the highest point of the facade wall. From Fig: 1, it is observed that the spacing angle of the actual latitude establishes a relationship with the road height and width (Right of way) between rows of building in urban canyon geometry. The relationship is expressed through the following formula:

Tan Ao $=\mathrm{H} / \mathrm{W}$

Where,

$\mathrm{A}=$ the spacing angle of the latitude,

$\mathrm{H}=$ the road height of the urban canyon, and

$\mathrm{W}=$ the right-of-way (ROW) between rows of building in urban canyon

When this formula is applied on all four sides of a block, a hip-roof-shaped pyramid will be formed above the road wall façade of well-defined rectangular volume which is termed as daylight envelope. Blocks may, therefore, be shaped to support the specified building height and desired DF planning goal. For a 215 lux goal, an standard DF of $1.25-2.0 \%$ is required in the North latitude class of $26.11^{\circ}$ of Guwahati. The Daylight Access Rule indicates that a $1.5 \%$ DF requires a maximum $\mathrm{H} / \mathrm{W}$ ratio of 1.26 , reminiscent of a $51.57^{\circ}$ minimum exposure plane.

\section{Solar envelope}

Solar envelope is often the most developable volume derived from the sun's motion with a specific site which will not shade adjacent building or site during critical times of the day in specific latitude [2]. The dimensions and shape of solar envelope vary with the scale of the plot, orientation, latitude, time of the day solar access is desired and amount of allowable shading on adjacent streets and building.

The solar envelope technique may be used as a urban planning technique of development control of an extension of zoning regulations and is meant to guard sunlight access to adjacent buildings and plot.

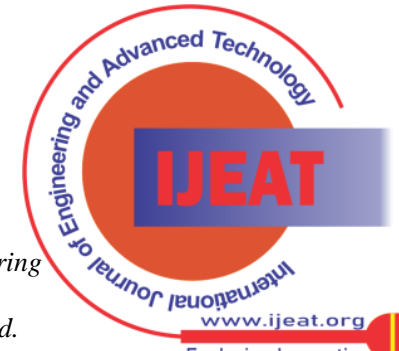


The dimension and shape of the solar envelope depends on the solar elevation angle (SEA) and also the Azimuth angle of particular latitude. Generally solar envelope is generated on 21 December when the solar elevation angle is minimum. Fig: 2 show the solar elevation angle (SEA) and azimuth angle of some extent on earth's surface.

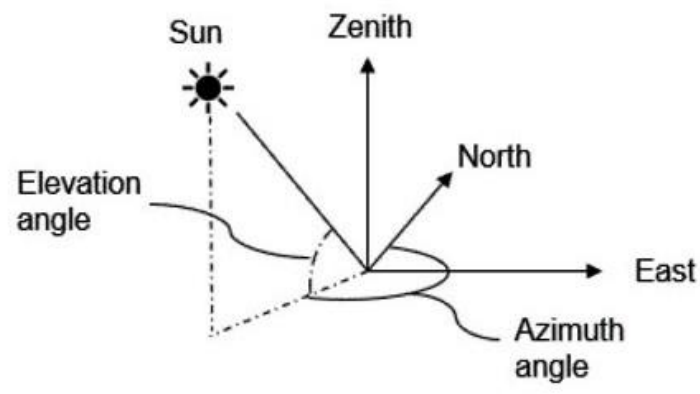

azimuth angle: north $=0$, east $=90$, south $=180$, west $=270$ degree

Fig.2 : Solar elevation angle and Azimuth angle [13]

\section{E. Natural ventilation in urban canyon environment}

In neighbourhood planning, cluster of building blocks around a central open space can accommodate spaces for better air exchange between indoor and outdoor areas [3]. The central open space is appeared to offer great potential to utilise natural cross ventilation that helps to take care of certain level of indoor thermal comfort. Climatic envelope helps to take care of an efficient height-to-width $(\mathrm{H} / \mathrm{W})$ ratio in urban street canyon geometry that enables wind forces to come up with airflows through the spaces between buildings and guide the air movement running through window openings in external walls. In summer, wind forces are often dominant and therefore the corridors inside the apartment act as wind tunnels to ventilate out hot air through the other window openings.
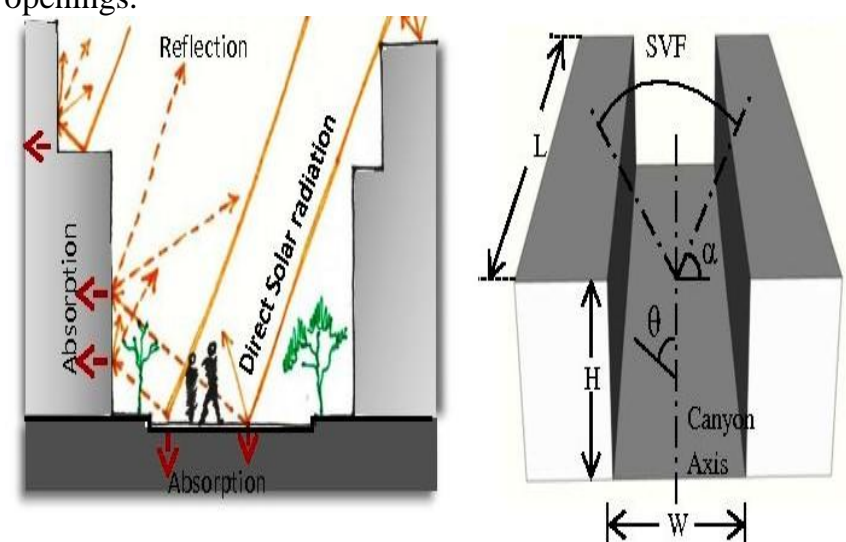

Fig.3 : Solar Radiation and Urban Canyon geometry [15]

In the urban street canyon, the mean velocity of wind is reduced significantly and also the wind direction is changed. As a result, wind-induced pressure on a building's surface is less. In urban spatial arrangement of buildings, urban canopy layer influences the airflow. The airflow within the urban canopy layer depends on the building envelopes, the geometry of the street canyon and the presence of other obstacle, like trees, and upon traffic. The geometry of the street canyon is characterized by $\mathrm{H}$ (mean height of buildings within the canyon), by $\mathrm{W}$ (the canyon width) and by $\mathrm{L}$ (the canyon length), shown in Fig: 3. Based on these values, the street canyon is determined by the $\mathrm{H} / \mathrm{W}$ ratio and also the $\mathrm{L} / \mathrm{H}$ ratio. When the predominant wind direction is parallel $( \pm 15$ degrees) to the street canyon the rate of inside airflow reduces as shown in table:3. When the predominant wind direction is perpendicular ( \pm 15 degrees) to the street canyon the rate of inside airflow reduces as shown in table: 4 .

Table: 3 Values for air speed inside the canyon when the wind blows parallel the canyon [12]

\begin{tabular}{|l|l|l|l|}
\hline $\begin{array}{l}\text { Wind velocity } \\
\text { outside the } \\
\text { canyon }(\mathrm{U})\end{array}$ & $\begin{array}{l}\text { Wind velocity inside } \\
\text { the canyon }\end{array}$ & \multicolumn{2}{|l|}{$\begin{array}{l}\text { Typical wind velocity values in the } \\
\text { canyon }\end{array}$} \\
\cline { 3 - 4 } & & Lowest part & Highest part \\
\hline $0<\mathrm{U}<1.0$ & $0.30-0.70 \mathrm{~m} / \mathrm{s}$ & $0.30 \mathrm{~m} / \mathrm{s}$ & $0.70 \mathrm{~m} / \mathrm{s}$ \\
\hline $1.0<\mathrm{U}<2.0$ & $0.40-1.30 \mathrm{~m} / \mathrm{s}$ & $0.40 \mathrm{~m} / \mathrm{s}$ & $1.30 \mathrm{~m} / \mathrm{s}$ \\
\hline $2.0<\mathrm{U}<3.0$ & $0.40-1.50 \mathrm{~m} / \mathrm{s}$ & $0.40 \mathrm{~m} / \mathrm{s}$ & $1.50 \mathrm{~m} / \mathrm{s}$ \\
\hline $3.0<\mathrm{U}<4.0$ & $0.40-2.20 \mathrm{~m} / \mathrm{s}$ & $0.40 \mathrm{~m} / \mathrm{s}$ & $2.20 \mathrm{~m} / \mathrm{s}$ \\
\hline
\end{tabular}

Table: 4 Values for air speed inside the canyon when the wind is perpendicular to the canyon [12]

\begin{tabular}{|l|l|l|l|}
\hline $\begin{array}{l}\text { Wind velocity } \\
\text { outside the canyon } \\
\text { (U) }\end{array}$ & \multicolumn{2}{|l|}{$\begin{array}{l}\text { Wind velocity inside the canyon } \\
\text { Near the windward facade of the } \\
\text { canyon }\end{array}$} & $\begin{array}{l}\text { Wind velocity inside the } \\
\text { canyon } \\
\text { Near the upwind facade } \\
\text { of the canyon }\end{array}$ \\
\cline { 2 - 4 } & Lowest part & Highest part & $0.40 \mathrm{~m} / \mathrm{s}$ \\
\hline $0<\mathrm{U}<1.0$ & $0.40 \mathrm{~m} / \mathrm{s}$ & $0.70 \mathrm{~m} / \mathrm{s}$ & $0.40 \mathrm{~m} / \mathrm{s}$ \\
\hline $1.0<\mathrm{U}<2.0$ & $0.40 \mathrm{~m} / \mathrm{s}$ & $1.30 \mathrm{~m} / \mathrm{s}$ & $0.60 \mathrm{~m} / \mathrm{s}$ \\
\hline $2.0<\mathrm{U}<3.0$ & $0.60 \mathrm{~m} / \mathrm{s}$ & $1.50 \mathrm{~m} / \mathrm{s}$ & $0.70 \mathrm{~m} / \mathrm{s}$ \\
\hline $3.0<\mathrm{U}<4.0$ & $0.70 \mathrm{~m} / \mathrm{s}$ & $3.00 \mathrm{~m} / \mathrm{s}$ & 0.62 \\
\hline
\end{tabular}

The keys to effective natural ventilation are the building orientation, the dimension and placing of the window openings in building façade [3]. For residential buildings in warm-humid climate, it's recommended to make window openings in opposite walls to permit cross ventilation in every room. Cross ventilation exchanges hot air inside with cool outside air. Window sizes and placement within the external wall determines the success of the ventilation strategy in a building. The average interior air velocity depends on the dimension and location of the openings, the angle between the wind direction and therefore the opening, and exterior wind velocity [3]. Acceptable indoor airflow depends on the temperature and humidity of indoor environment. At temperatures below $33^{\circ} \mathrm{C}$, a rise in air velocity increases the thermal comfort level [3].

\section{BIO CLIMATIC FACTORS AND DEVELOPMENT CONTROL RULES OF GUWAHATI}

Guwahati is situated at north latitude of $26^{\circ} 1445^{\prime}$, the east longitude of $91^{\circ} 7263^{\prime}$ and altitude of $54 \mathrm{~m}$ above sea level [3]. This city experiences an annual average temperature of $24.21^{\circ} \mathrm{C}$ and relative humidity more than $70 \%$. Prevailing regional wind direction is from SW to NE in summer with an average wind velocity of $6.9 \mathrm{~m} / \mathrm{s}$ and wind direction is from $\mathrm{NE}$ to SW in winter with an average velocity of $5.47 \mathrm{~m} / \mathrm{s}$ [3] (Table:5). The bio-climatic data of Guwahati projects comfort condition in winter and early summer months (14.17\% days of the year), whereas conventional air-conditioning is required for $53.75 \%$ days of the year due to high humid condition during summer months [3]. The potentiality of natural ventilation is about $16.7 \%$ [3] (Fig:5). Fig: $4 \& 5$ represents the potential energy usage and potential energy savings depending upon the building design, orientation, and surrounding developments [3].

Published By:

Blue Eyes Intelligence Engineering and Sciences Publication

DOI:10.35940/ijeat.C2208.0210321

Journal Website: www.ijeat.org 


\section{Climatic Envelope as an Urban Planning Tool to Configure Urban Fabric of Guwahati City to Support Daylight and Natural Ventilation}

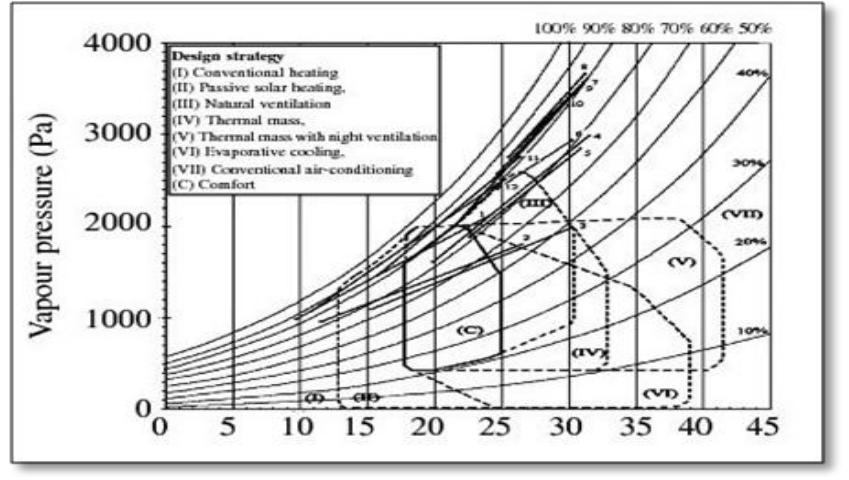

Fig. 4: Bio-climatic chart of Guwahati [16]

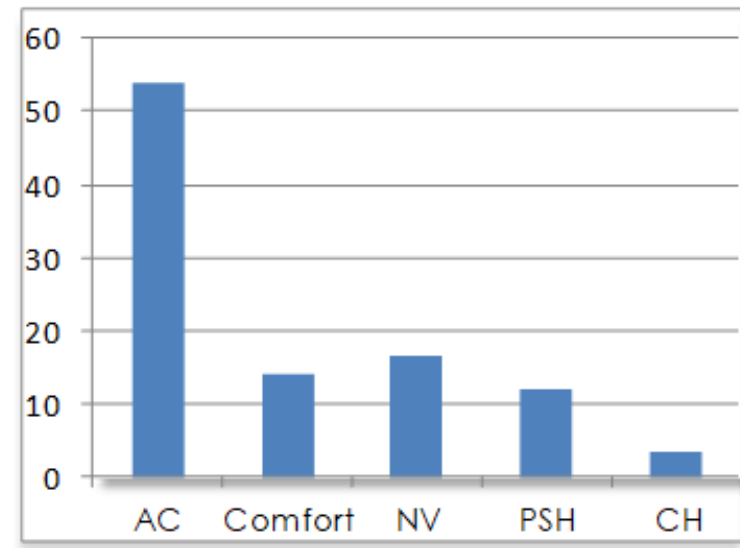

Fig.5: potential Passive design strategies [3]

Local climate of Guwahati is influenced by seasonal air temperatures, annual rainfall, relative humidity, wind speed and wind directions as per meteorological data of the city [3] (Table:5).

Table:5 Meteorological data of Guwahati from Sept. 2018 to August 2019 [3]

\begin{tabular}{|c|c|c|c|c|c|c|}
\hline \multirow{2}{*}{ Month } & \multirow{2}{*}{$\begin{array}{l}\text { Rainfall } \\
(\mathrm{mm})\end{array}$} & \multicolumn{2}{|c|}{ Air Temp. } & \multirow{2}{*}{$\begin{array}{l}\text { Wind Speed } \\
\text { Avg }(\mathrm{Km} / \mathrm{h})\end{array}$} & \multirow{2}{*}{$\begin{array}{c}\text { Wind } \\
\text { Direction }\end{array}$} & \multirow{2}{*}{$\begin{array}{l}\mathrm{RH} \\
(\%)\end{array}$} \\
\hline & & Max. & Min. & & & \\
\hline Sept. 2018 & 179.72 & 31 & 24 & 4.2 & W,SW & $81 \%$ \\
\hline Oct. 2018 & 148.70 & 30 & 21 & 5.1 & E,SE,NE & $74 \%$ \\
\hline Nov. 2018 & 16.20 & 27 & 18 & 5.4 & E,SE,NE & $71 \%$ \\
\hline Dec. 2018 & 62.6 & 24 & 15 & 5.4 & E,SE,NE & $70 \%$ \\
\hline Jan. 2019 & 3.90 & 25 & 15 & 5.8 & E,SE,NE & $57 \%$ \\
\hline Feb. 2019 & 48.90 & 27 & 16 & 6.9 & E,SE,NW & $59 \%$ \\
\hline Mar. 2019 & 22.70 & 31 & 19 & 7.9 & E,SE,SW & $46 \%$ \\
\hline April 2019 & 224.20 & 34 & 23 & 7.4 & E,SE,SW & $57 \%$ \\
\hline May 2019 & 639.60 & 34 & 24 & 8.6 & E,SE,SW & $73 \%$ \\
\hline June 2019 & 536.80 & 35 & 26 & 5.2 & W,SW & $74 \%$ \\
\hline July 2019 & 1172.60 & 32 & 25 & 6.3 & W,SW & $85 \%$ \\
\hline $\begin{array}{l}\text { August } \\
2019\end{array}$ & 694.00 & 34 & 27 & 6.0 & W,SW & $78 \%$ \\
\hline
\end{tabular}

A. Urban design regulations in residential zones of Guwahati

Urban development pattern in Guwahati is governed by GMDA Building bye-laws and Guwahati Master Plan Zoning for the year 2025 [3]. The land-use zones consist of residential, commercial, industrial, and Public/Semi-public areas. GMDA bye-laws specify provisions for the number of floors, building height, road width, building percentage (plot/ground coverage), floor area ratio (FAR) and building setbacks [3]. Four distinguished plot typologies of A, B, C, and $\mathrm{D}$ are designated to develop residential zone in Guwahati [3]. The sizes of plot for various residential segments vary between below $670 \mathrm{~m}^{2}$ (sector A) to above $6670 \mathrm{~m}^{2}$ (sector D)
[3]. The provisions of plot coverage, number of floors, building height, setbacks and also the maximum FAR for each sector are shown in Table: 6 .

Table 6: GMDA bye law provisions for residential plot typologies of A, B, C and D [10]

\begin{tabular}{|c|c|c|c|c|c|c|c|c|}
\hline \multirow{2}{*}{$\begin{array}{l}\text { Resi.plot } \\
\text { type }\end{array}$} & \multirow{2}{*}{$\begin{array}{l}\text { Road } \\
\text { Width(m) }\end{array}$} & \multirow{2}{*}{$\begin{array}{l}\text { Max. } \\
\text { plot } \\
\text { coverage }\end{array}$} & \multirow{2}{*}{$\begin{array}{l}\text { Max. } \\
\text { no. of } \\
\text { floors }\end{array}$} & \multirow{2}{*}{$\begin{array}{l}\text { Max } \\
\text { FAR }\end{array}$} & \multirow{2}{*}{$\begin{array}{l}\text { Max. } \\
\text { height } \\
\text { (m) }\end{array}$} & \multicolumn{3}{|c|}{ Setback (m) } \\
\hline & & & & & & $\mathrm{F}$ & $\mathrm{B}$ & $\mathrm{S}$ \\
\hline \multirow{5}{*}{$\begin{array}{l}\text { A } \\
\text { (up to } \\
670 \\
\text { Sqm) }\end{array}$} & 3.6 to 4.5 & $60 \%$ & $\mathrm{G}+2$ & 1.00 & 9.6 & 3.6 & 1.8 & 1.8 \\
\hline & 4.5 to 6.6 & $60 \%$ & $\mathrm{G}+3$ & 1.25 & 12.6 & 4.5 & 2.4 & 2.4 \\
\hline & 6.6 to 8.0 & $55 \%$ & $\mathrm{G}+4$ & 1.50 & 15.6 & 6.0 & 3.6 & 3.6 \\
\hline & $\begin{array}{l}8.0 \text { to } \\
15.0\end{array}$ & $50 \%$ & $\mathrm{G}+4$ & 1.50 & 15.6 & 6.0 & 3.6 & 3.6 \\
\hline & $\begin{array}{l}\text { Above } \\
15.0\end{array}$ & $50 \%$ & $\mathrm{G}+5$ & 1.75 & 18.6 & 9.0 & 4.2 & 4.2 \\
\hline \multirow{5}{*}{$\begin{array}{l}B \\
\text { (above } \\
670 \text { to } \\
1338 \\
\text { sqm) }\end{array}$} & 3.6 to 4.5 & $50 \%$ & $\mathrm{G}+2$ & 1.00 & 9.6 & 3.6 & 1.8 & 1.8 \\
\hline & 4.5 to 6.6 & $50 \%$ & $\mathrm{G}+4$ & 1.25 & 15.6 & 4.5 & 3.6 & 3.6 \\
\hline & 6.6 to 8.0 & $50 \%$ & $\mathrm{G}+4$ & 1.60 & 18.6 & 9.0 & 4.2 & 4.2 \\
\hline & $\begin{array}{l}8.0 \text { to } \\
15.0\end{array}$ & $45 \%$ & $\mathrm{G}+8$ & 1.75 & 27.6 & 9.0 & 6.0 & 6.0 \\
\hline & $\begin{array}{l}\text { Above } \\
15.0\end{array}$ & $40 \%$ & $\mathrm{G}+8$ & 1.75 & 27.6 & $\begin{array}{l}=9 . \\
0<\end{array}$ & 6.0 & 6.0 \\
\hline \multirow{5}{*}{$\begin{array}{l}\mathrm{C} \\
\text { (above } \\
1338 \text { to } \\
6690 \\
\text { sqm) }\end{array}$} & 3.6 to 4.5 & $50 \%$ & $\mathrm{G}+2$ & 1.25 & 9.6 & 3.6 & 1.8 & 1.8 \\
\hline & 4.5 to 6.6 & $50 \%$ & $\mathrm{G}+5$ & 1.25 & 18.6 & 9.0 & 4.2 & 4.2 \\
\hline & 6.6 to 8.0 & $45 \%$ & $\mathrm{G}+7$ & 1.75 & 24.6 & 9.0 & 5.5 & 5.5 \\
\hline & $\begin{array}{l}8.0 \text { to } \\
15.0\end{array}$ & $40 \%$ & $\begin{array}{l}\text { No } \\
\text { Limit }\end{array}$ & 2.25 & $\begin{array}{c}\text { No } \\
\text { Limit }\end{array}$ & 9.0 & $\begin{array}{l}=7 . \\
0<\end{array}$ & $\begin{array}{l}=7 . \\
0<\end{array}$ \\
\hline & $\begin{array}{l}\text { Above } \\
15.0\end{array}$ & $40 \%$ & $\begin{array}{l}\text { No } \\
\text { Limit }\end{array}$ & 2.25 & $\begin{array}{c}\text { No } \\
\text { Limit }\end{array}$ & $\begin{array}{l}=9 . \\
0<\end{array}$ & $\begin{array}{l}=7 . \\
0<\end{array}$ & $\begin{array}{l}=7 . \\
0<\end{array}$ \\
\hline \multirow{5}{*}{$\begin{array}{l}\text { D } \\
\text { (above } \\
6690 \\
\text { sqm) }\end{array}$} & 3.6 to 4.5 & $45 \%$ & $\mathrm{G}+3$ & 1.25 & 12.6 & 4.5 & 2.4 & 2.4 \\
\hline & 4.5 to 6.6 & $45 \%$ & $\mathrm{G}+5$ & 1.50 & 18.6 & 9.0 & 4.2 & 4.2 \\
\hline & 6.6 to 8.0 & $40 \%$ & $\mathrm{G}+7$ & 1.75 & 24.6 & 9.0 & 5.5 & 5.5 \\
\hline & $\begin{array}{l}8.0 \text { to } \\
15.0\end{array}$ & $40 \%$ & $\begin{array}{l}\text { No } \\
\text { Limit }\end{array}$ & 2.25 & $\begin{array}{l}\text { No } \\
\text { Limit }\end{array}$ & 9.0 & $\begin{array}{l}=7 \\
0<\end{array}$ & $\begin{array}{l}=7 . \\
0<\end{array}$ \\
\hline & $\begin{array}{l}\text { Above } \\
15.0\end{array}$ & $40 \%$ & $\begin{array}{l}\text { No } \\
\text { Limit }\end{array}$ & 2.50 & $\begin{array}{l}\text { No } \\
\text { Limit }\end{array}$ & $\begin{array}{l}=9 . \\
0<\end{array}$ & $\begin{array}{l}=7 . \\
0<\end{array}$ & $\begin{array}{l}=7 . \\
0<\end{array}$ \\
\hline
\end{tabular}

The Residential apartment buildings are designated to develop within the three plot typologies of B, C, and D [3]. GMDA building bye-law keeps a provision of minimum $16.67 \%$ WFR in every habitable room and habitable rooms should face a minimum of one external wall [3]. In Guwahati, there's little knowledge of the actual ventilation rate in apartments [3]. During this study, the ventilation rate is measured in a typical apartment of existing spatial arrangement of buildings.

\section{METHODOLOGY}

\section{A. Case study area: National Games Village, Borsajai, Guwahati [3]}

Based on the GMDA building bye-laws and development regulations of building height, street width and setbacks, an existing residential neighbourhood of National Games Village [3] (Fig: 6) at Borsajai, Guwahati is chosen as case study area for climatic envelope analysis and Microclimate simulations. The campus was developed by GMDA as a MIG group housing scheme in the year 2007 [3]. 616 residential apartments were sold to individual middle-income group families [3]. Present population of the neighbourhood is approximately 3080 with a building density of 132 apartments/hectares [3]. The neighbourhood is developed on D type residential plot. National Games Village is a simplified cluster of typical geometric patterns, material properties, facade colours and ground elements [3].

Published By:

Blue Eyes Intelligence Engineering and Sciences Publication 


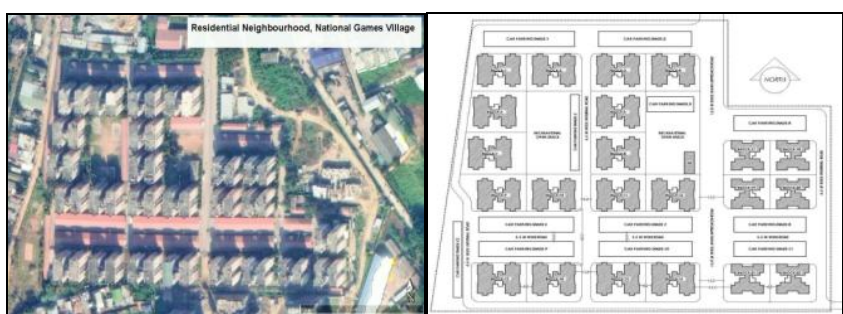

Fig. 6: satellite map of case study area (left) and master plan of residential neighbourhood (right) of National

Games Village, Borsajai, Guwahati [2, 3].

The southern part of the cluster consists of two rows of plots with six plots on each side with a $40 \mathrm{~m}$ wide right of way (Fig:6) in E-W direction [3]. The buildings are $21.6 \mathrm{~m}$ high (G+6 storied). The street width is $6.6 \mathrm{~m}$ within the predetermined minimum street width of $6.6 \mathrm{~m}$ to $8.0 \mathrm{~m}$. The setbacks are in agreement with the development rules (front $=$ 9.0 rear setbacks $=6.0 \mathrm{~m}$, side setbacks $=4.0 \mathrm{~m}$ ) [3]. All the cluster of buildings is developed with different height-to-width ratio $(\mathrm{H} / \mathrm{W})$ of $0.54,0.92,1.56$ and 2.70 as shown in Fig: $7 \& 8$.

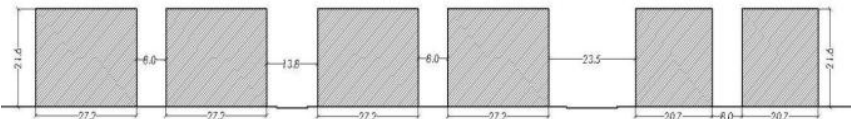

Fig. 7: section of the model area of the base case with $\mathrm{H} / \mathrm{W}$ ratio of $0.92,1.56,2.70$ in $\mathrm{N}-\mathrm{S}$ direction [3].

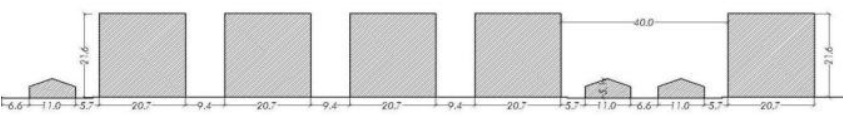

Fig. 8: Section of the model area of the base case with $\mathrm{H} / \mathrm{W}$ ratio of 0.54 in $\mathrm{E}-\mathrm{W}$ direction [3].

B. Construction of daylight envelope using daylight spacing angle (DSA) in Guwahati

Daylight spacing angles is a simple technique, conceptualised to space parallel rows of residential buildings. Daylight spacing angle techniques addresses the prescriptive street wall for a given street width and suggest an $\mathrm{H} / \mathrm{W}$ ratio through respective sky exposure angle. The spacing angle is related with particular latitude and for Guwahati at latitude of $26.11^{\circ}$ north, the minimum daylight spacing angle is $51.57^{\circ}$. A study is carried out by applying daylight spacing angle technique in an existing residential complex within the Guwahati Metropolitan Area (GMA). This method is used to understand the importance of the urban density variations by applying it in national games village, a MIG residential complex of twenty two building blocks of $27.15 \mathrm{~m}$ x $20.65 \mathrm{~m}$ at $26.11 \mathrm{o}$ north latitude of Guwahati. The envelope generated by this system is shown in Fig: 9. Gross volume and gross FAR permitted by the constructed envelop is considered for every tool for an existing building block of $21 \mathrm{~m}$ tall in height with a story height of $3 \mathrm{~m}$. The angle of the exposure plane is additionally also listed in table: 7.0

Table: 7 Daylight spacing angle technique

\begin{tabular}{|l|l|c|c|c|c|}
\hline $\begin{array}{l}\text { Daylight } \\
\text { Technique }\end{array}$ & Variables used & DSA & $\begin{array}{l}\text { ROW } \\
(\mathrm{m})\end{array}$ & $\begin{array}{l}\text { Heigh } \\
\mathrm{t}(\mathrm{m})\end{array}$ & $\begin{array}{l}\mathrm{H} / \mathrm{W} \\
\text { ratio }\end{array}$ \\
\hline DSA & $\begin{array}{l}\text { 1.Daylight spacing } \\
\text { angle }\end{array}$ & 51.57 & $10.0 \mathrm{~m}$ & $15.6 \mathrm{~m}$ & 1.56 \\
\cline { 2 - 3 } & $\begin{array}{l}\text { 2.Latitude 26.11 deg. } \\
\mathrm{N}\end{array}$ & & & & \\
\cline { 2 - 3 } & $\begin{array}{l}\text { 3.Ground floor stilt } \\
\text { parking shading } \\
\text { allowed }\end{array}$ & & & & \\
\hline
\end{tabular}

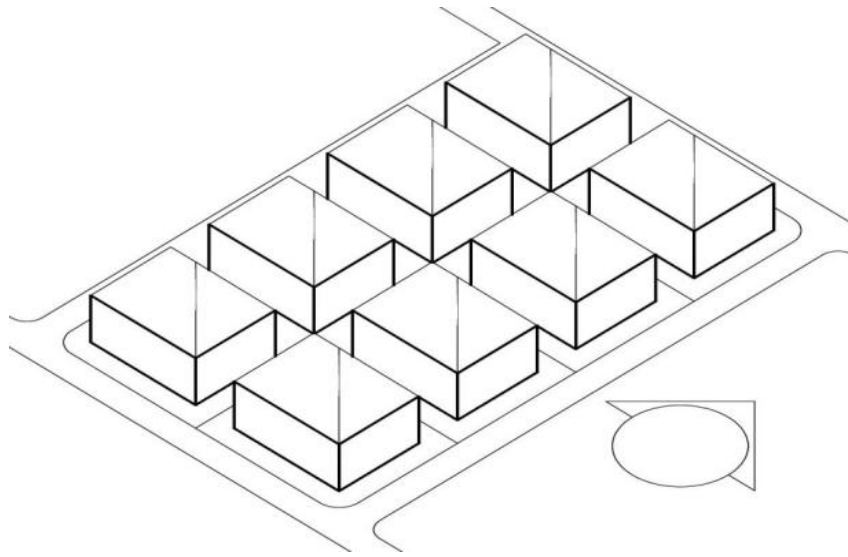

Fig: 9 construction of building envelope of national games village using daylight spacing angle

\section{Construction of solar envelope in case study area of} National Games Village, Guwahati

Solar envelope defines maximum developable volume derived from the sun's motion at a specific site that may not shade adjacent building or site during critical times. The dimension and shape of solar envelope vary with the dimension of the plot, orientation, latitude, time of the day solar access is desired and amount of allowable shading on adjacent streets and building. It's used as a way of development control, as an extension of zoning regulations and is meant to guard sunlight access. Sun light is the only potential natural energy source to contribute significantly to interior building illumination. The solar envelop may be a technique limiting development bulk and limits development to moderate densities, therefore it has the potential to confirm sufficient day light access to building interior. Table. 8 shows the solar elevation angle and azimuth angle of National Games Village of Guwahati at 9.00 AM on 21 Dec. 2019. Like daylight spacing angle (DSA), Solar envelope technique is also used to understand the importance of the urban density variations by applying it in national games village, a MIG residential complex of twenty two building blocks of $27.15 \mathrm{~m}$ x $20.65 \mathrm{~m}$ at 26.11 o north latitude of Guwahati. The envelope generated by this method is shown in fig: 6 . Gross volume and gross FAR permitted by the constructed envelop is considered for each tool for an existing building block of $21 \mathrm{~m}$ in height with a story height of $3 \mathrm{~m}$. The angle of the exposure plane is additionally listed in table: 9 .

Table: 8 Solar elevation angle and Azimuth angle of Guwahati [12]

\begin{tabular}{|c|c|c|}
\hline Time in hh:mm & $\begin{array}{c}\text { Solar Elevation Angle } \\
\text { (degree) }\end{array}$ & Azimuth Angle (degree) \\
\hline $09.00 \mathrm{AM}$ & 22.71 & 133.21 \\
\hline $10.00 \mathrm{AM}$ & 31.54 & 145.07 \\
\hline $11.00 \mathrm{AM}$ & 37.78 & 160.00 \\
\hline $12.00 \mathrm{PM}$ & 40.43 & 177.41 \\
\hline $01.00 \mathrm{PM}$ & 38.94 & 195.20 \\
\hline $02.00 \mathrm{PM}$ & 33.63 & 210.96 \\
\hline $03.00 \mathrm{PM}$ & 25.45 & 223.68 \\
\hline
\end{tabular}




\section{Climatic Envelope as an Urban Planning Tool to Configure Urban Fabric of Guwahati City to Support Daylight and Natural Ventilation}
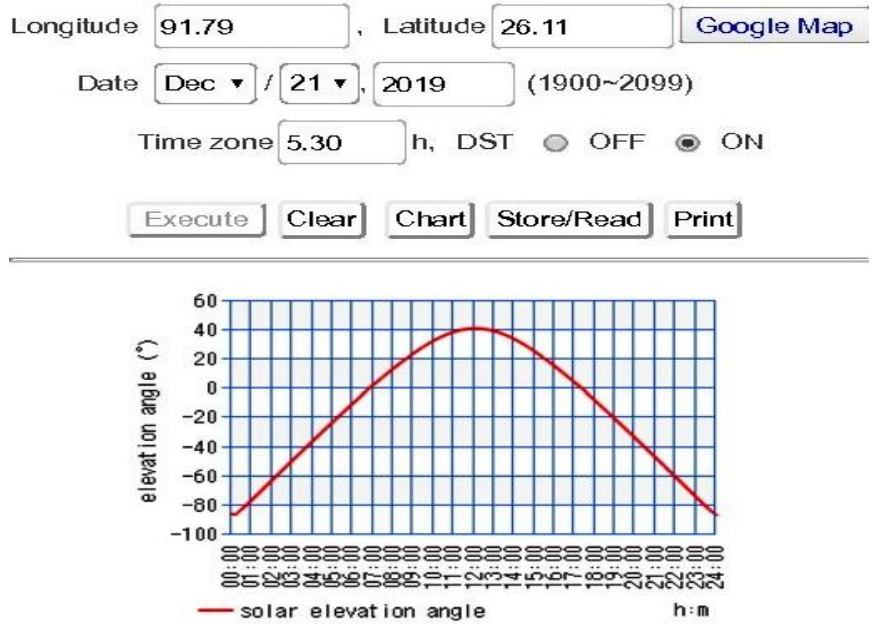

Fig: 10 solar elevation angle and azimuth angle of Guwahati at 9.00AM, Dec21, 2019 [2]

Table: 9 solar envelope techniques

\begin{tabular}{|c|c|c|c|c|c|}
\hline Technique & Variables used & $\begin{array}{c}\text { SEA } \\
\text { (degree } \\
\text { ) }\end{array}$ & $\begin{array}{l}\text { ROW } \\
\text { (m) }\end{array}$ & $\begin{array}{l}\text { Wall } \\
\text { Height } \\
(\mathrm{m})\end{array}$ & $\begin{array}{l}\mathrm{H} / \mathrm{W} \\
\text { ratio }\end{array}$ \\
\hline \multirow[t]{3}{*}{$\begin{array}{l}\text { Solar } \\
\text { envelope }\end{array}$} & $\begin{array}{l}\text { 1.Latitude } 26.11 \\
\text { deg. } \mathrm{N}\end{array}$ & \multirow[t]{3}{*}{$22.71^{0}$} & \multirow[t]{3}{*}{$10.0 \mathrm{~m}$} & \multirow[t]{3}{*}{$12.6 \mathrm{~m}$} & \multirow[t]{3}{*}{1.26} \\
\hline & $\begin{array}{l}\text { 2.Solar elevation } \\
\text { angle and } \\
\text { azimuthal angle }\end{array}$ & & & & \\
\hline & $\begin{array}{l}\text { 3.Lower two } \\
\text { stories shading } \\
\text { allowed }\end{array}$ & & & & \\
\hline
\end{tabular}

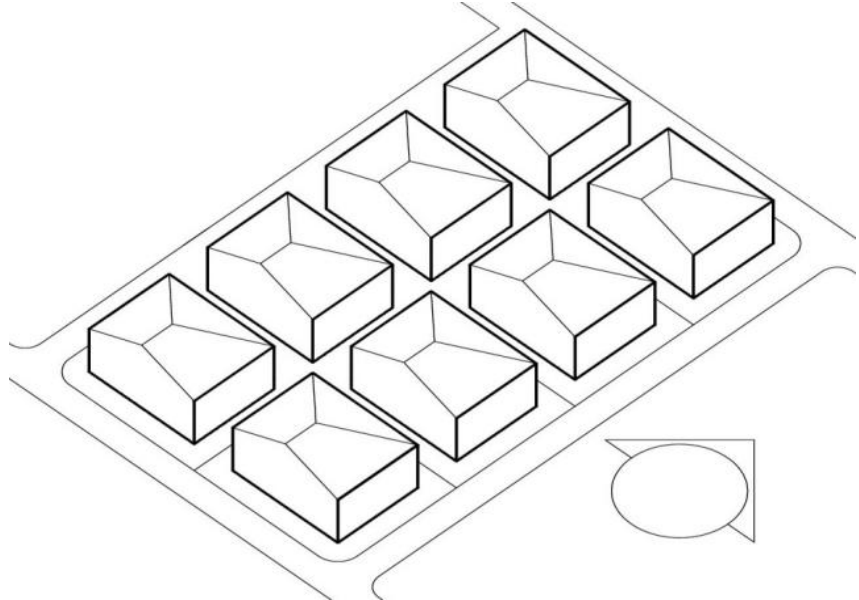

Fig: 11 construction of building envelope of national games village using solar envelope techniques

D. Comparison of maximum allowable volume (MAV) and permissible FAR for density implications

Both daylight envelope and solar envelope address the prescriptive street wall differently for a given street width and suggest a unique $\mathrm{H} / \mathrm{W}$ ratio through respective sky exposure angle. Each planning technique suggests different developable volume with the identical prescriptive road width. A comparative study is made to understand the importance of the urban density variations by applying these daylight planning tools in an existing residential complex within the Guwahati Metropolitan Area (GMA).

Table: 10 show the FAR and Maximum Allowable Volume (MAV) calculations of the case study building for various daylight planning techniques.

Plot area of the case study building block $=1138.65$ Sqm
Table: 10 FAR and maximum developable volume and total floor area

\begin{tabular}{|c|c|c|c|c|c|c|c|}
\hline $\begin{array}{l}\text { Daylig } \\
\text { ht } \\
\text { Planni } \\
\text { ng } \\
\text { Tools }\end{array}$ & $\begin{array}{l}\text { Total } \\
\text { floor } \\
\text { area } \\
\text { (Sqm) }\end{array}$ & $\begin{array}{l}\text { Str. } \\
\text { Wall } \\
\text { Heig } \\
\text { ht } \\
(\mathrm{m})\end{array}$ & $\begin{array}{l}\text { M } \\
\mathrm{AV} \\
(\mathrm{Cu} \\
\mathrm{m})\end{array}$ & $\begin{array}{l}\text { Cover } \\
\text { age } \\
(\%)\end{array}$ & $\begin{array}{l}\mathrm{F} \\
\mathrm{A} \\
\mathrm{R}\end{array}$ & $\begin{array}{l}\text { GMD } \\
\text { A } \\
\text { FAR }\end{array}$ & Remark \\
\hline $\begin{array}{l}\text { Daylig } \\
\text { ht } \\
\text { envelo } \\
\text { pe }\end{array}$ & $\begin{array}{l}2787 . \\
5\end{array}$ & 15.6 & $\begin{array}{r}927 \\
0\end{array}$ & $45 \%$ & $\begin{array}{l}2 . \\
62\end{array}$ & 1.75 & $\begin{array}{l}\text { FAR is } \\
\text { more than } \\
\text { GMDA } \\
\text { FAR }\end{array}$ \\
\hline $\begin{array}{l}\text { Solar } \\
\text { Envelo } \\
\text { pe }\end{array}$ & $\begin{array}{l}2387 . \\
5\end{array}$ & 12.6 & $\begin{array}{r}747 \\
0\end{array}$ & $45 \%$ & $\begin{array}{l}2 . \\
10\end{array}$ & 1.75 & $\begin{array}{l}\text { FAR is } \\
\text { more than } \\
\text { GMDA } \\
\text { FAR }\end{array}$ \\
\hline
\end{tabular}

The planning tools of Daylight spacing angle (DSA) and Solar elevation angle (SEA) are conceptualised to manage sky exposure plane angle by limiting street wall height and spacing between adjacent buildings. In all the cases, Ground coverage kept at maximum $45 \%$ as per GMDA regulations. $\mathrm{H} / \mathrm{W}$ ratio recommendations vary between 1.26 to 1.56 . Maximum Allowable Volumes (MAV) allowed among daylight planning tools vary from FAR 2.1 to FAR 2.62. The lowest FAR and MAV is generated by the solar envelope. Table: 11 show the comparative analysis of the most allowable volume (MAV) and FAR for various daylight planning tools.

Table: 11 comparative analysis of FAR and maximum developable volume

\begin{tabular}{|l|c|l|c|l|l|}
\hline $\begin{array}{l}\text { Daylight } \\
\text { Planning } \\
\text { Tools }\end{array}$ & $\begin{array}{l}\text { H/ } \\
\text { W } \\
\text { rati } \\
\text { o }\end{array}$ & $\begin{array}{l}\text { MA } \\
\text { V } \\
(\mathrm{Cu} \\
\mathrm{m})\end{array}$ & $\begin{array}{l}\text { FA } \\
\mathrm{R}\end{array}$ & $\begin{array}{l}\text { Exposu } \\
\text { re } \\
\text { Plane } \\
\text { angle }\end{array}$ & Remark \\
\hline $\begin{array}{l}\text { Daylight } \\
\text { envelope }\end{array}$ & $\begin{array}{c}1.5 \\
6\end{array}$ & 9270 & $\begin{array}{c}2.6 \\
2\end{array}$ & $51.57^{\circ}$ & $\begin{array}{l}\text { Daylight reaches to } \\
\text { ground floor }\end{array}$ \\
\hline $\begin{array}{l}\text { Solar } \\
\text { Envelope } \\
\text { on 21 Dec. }\end{array}$ & $\begin{array}{c}1.2 \\
6\end{array}$ & 7470 & $\begin{array}{c}2.1 \\
0\end{array}$ & $22.71^{\circ}$ & $\begin{array}{l}\text { Daylight reaches to } \\
\text { ground floor and solar } \\
\text { radiation reaches to } \\
\text { 2nd floor }\end{array}$ \\
\hline
\end{tabular}

E. Construction of composite climatic envelope in National Games Village, Guwahati

Construction of Climatic envelope explores the likelihood of applying daylight and solar envelope techniques to construct a composite envelope within the residential zone of inner-city areas of Guwahati. The climatic envelope technique ensures sufficient access of daylight to maintain a better daylight factor (DF) inside the building. Higher daylight factor (DF) helps to keep up adequate illumination level in different rooms ensuring a decrease in energy consumption. The volume and geometry of the climatic envelopes vary with the size of the block and orientation. Climatic envelope also helps to keep up an efficient height-to-width (H/W) ratio in urban street canyon geometry that permits solar radiation to adjacent buildings at the identical time provides shades to pedestrian activities. The climatic envelope technique is employed in national games village, a MIG residential complex of twenty two building blocks of $27.15 \mathrm{~m}$ x $20.65 \mathrm{~m}$ at 26.11 o north latitude of Guwahati. The envelope generated by this method is shown in Fig: 12. Gross volume and gross FAR allowed by the generated climatic envelop is calculated for an existing $\mathrm{G}+7$ storied building block of $21 \mathrm{~m}$ tall in height.

Published By:

Blue Eyes Intelligence Engineering and Sciences Publication 
The comparative statement of angle of the exposure plane for DSA and SEA, H/W ratio, maximum ground coverage, and allowable FAR and maximum allowable volume of climatic envelope are shown in Table: 12.

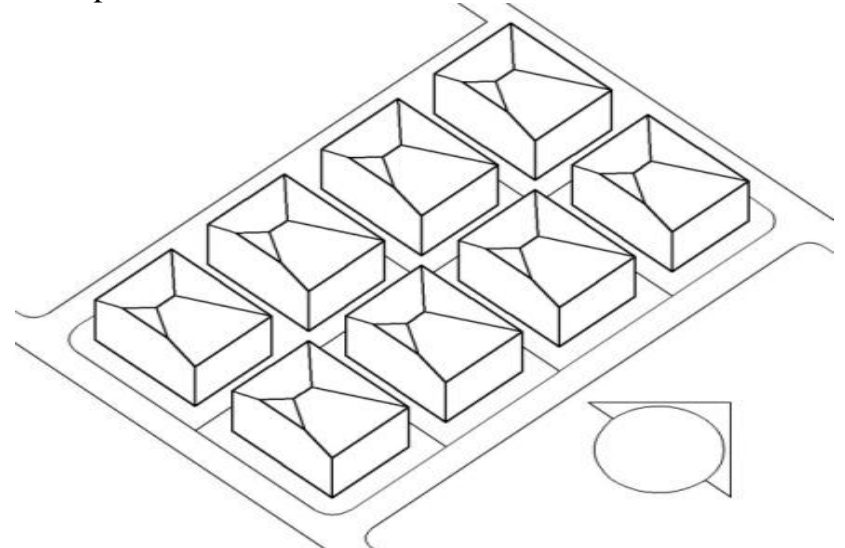

Fig: 12 Constructed climatic envelope combining daylight envelope and solar envelope

Table: 12 Maximum allowable volumes and FAR in climatic envelope [2]

\begin{tabular}{|c|c|c|c|c|c|c|c|}
\hline \multirow[t]{2}{*}{$\begin{array}{l}\text { Plannin } \\
\text { g Tool }\end{array}$} & \multirow{2}{*}{$\begin{array}{l}\mathrm{H} / \\
\mathrm{W} \\
\text { rati } \\
0\end{array}$} & \multirow{2}{*}{$\begin{array}{l}\text { Ground } \\
\text { coverag } \\
\text { e }\end{array}$} & \multirow{2}{*}{$\begin{array}{l}\text { MA } \\
\text { V } \\
(\mathrm{Cu} \\
\mathrm{m})\end{array}$} & \multirow{2}{*}{$\begin{array}{l}\text { Allowa } \\
\text { ble } \\
\text { FAR }\end{array}$} & \multicolumn{2}{|c|}{$\begin{array}{l}\text { Exposure } \\
\text { Plane angle }\end{array}$} & \multirow{2}{*}{$\begin{array}{l}\text { Permis } \\
\text { sible } \\
\text { FAR by } \\
\text { GMDA }\end{array}$} \\
\hline & & & & & DSA & SEA & \\
\hline $\begin{array}{l}\text { Climati } \\
\text { c } \\
\text { envelop } \\
\text { e }\end{array}$ & $\begin{array}{c}1.2 \\
6\end{array}$ & $45 \%$ & $\begin{array}{c}747 \\
0\end{array}$ & 2.10 & $\begin{array}{c}51.5 \\
7^{\circ}\end{array}$ & $\begin{array}{c}22.7 \\
1^{\circ}\end{array}$ & 1.75 \\
\hline $\begin{array}{l}\text { Remar } \\
\mathrm{k}\end{array}$ & \multicolumn{7}{|c|}{$\begin{array}{l}\text { Daylight reaches to ground floor and solar radiation reaches to } \\
\text { 2nd floor while allowable FAR is more than the permissible } \\
\text { FAR of GMDA }\end{array}$} \\
\hline
\end{tabular}

\section{F. Natural ventilation in buildings of Guwahati}

The window openings in building façade are main ventilation element that has access to natural ventilation in residential apartments of Guwahati. The factors that affect natural ventilation are the building orientation, the position of the windows in building facade and window-to-floor area ratio (WFR) of room [3]. National building code suggests different WFR \% for different climatic zone. the minimum WFR requirement for different climatic zones in India are shown in Table: 8.

Table: 8 Minimum requirement of window-to-floor area (WFR) ratio $[7,8]$

\begin{tabular}{|l|c|}
\hline Climatic Zone & Minimum WFR op $_{\text {op }}$ \\
\hline Composite & 12.50 \\
\hline Hot-Dry & 10.00 \\
\hline Warm-Humid & 16.66 \\
\hline Temperate & 12.50 \\
\hline Cold & 8.33 \\
\hline
\end{tabular}

Guwahati falls in warm-humid climatic zone and humidity plays important role in indoor comfort condition in residential buildings. During summer, when the outside temperature is lower than indoor temperature, cross ventilation cools down the indoor room environment by replacing hot indoor air with outside cool air. Cross ventilation of air also helps to cool down entire build-mass. Meanwhile, when the outside temperature is more, cross ventilation causes direct cooling on the body by means of evaporation and convection. So, it is recommended to keep more openings especially in opposite walls to permit cross ventilation in residential buildings of Guwahati. The average interior air velocity depends on \% of WFR, location of the openings, the angle of the wind direction and exterior wind velocity [3]. Suitable inside air movement depends on the

temperature and humidity of the environment. At temperatures below $33^{0} \mathrm{C}$, a rise in air velocity increases the thermal comfort level.

\section{MICROCLIMATE SIMULATIONS}

To study the outdoor thermal impacts of climate parameters, the thermal simulation software ENVI MET 4.0 for outdoor micro climate simulation of national games village [3]. The software ENVI-met, version 4.0 combines the calculation of fluid dynamics parameters like wind flow and turbulence with the thermodynamic processes happening on the bottom surfaces, walls, roofs and within the vegetation [3]. Input data of various variables are shown in Table:9 for summer and winter case study simulations.

Table 9: Input data for the summer and winter case study simulations [3]

\begin{tabular}{|l|l|l|}
\hline Variables/Description & Summer & Winter \\
\hline Building height, $\mathrm{H}(\mathrm{m})$ & 21.6 & 21.6 \\
\hline $\begin{array}{l}\text { Distance between buildings, } \\
\text { W }(\mathrm{m})\end{array}$ & $40,23.5,13.8,8$ & $40,23.5,13.8,8$ \\
\hline $\mathrm{H} / \mathrm{W}$ ratio & $0.54,0.92,1.56,2.7$ & $0.54,0.92,1.56,2.7$ \\
\hline $\begin{array}{l}\text { Wind speed (at } 1.5 \mathrm{~m} \text { height) } \\
(\mathrm{m} / \mathrm{s})\end{array}$ & 3.0 & 4.0 \\
\hline $\begin{array}{l}\text { Max. Indoor temperature } \\
\left({ }^{\circ} \mathrm{C}\right)\end{array}$ & 33 & 22 \\
\hline U-value, walls $\left(\mathrm{W} / \mathrm{m}^{2 \circ} \mathrm{C}\right)$ & 2.77 & 2.77 \\
\hline U-value, roof $\left(\mathrm{W} / \mathrm{m}^{2} \mathrm{C}\right)$ & 2.49 & 2.49 \\
\hline Reflectivity, facades & 0.40 & 0.40 \\
\hline Reflectivity, roofs & 0.25 & 0.25 \\
\hline Reflectivity, street, surface & 0.25 & 0.25 \\
\hline
\end{tabular}

\section{A. Outdoor Air temperature}

The simulated results of outdoor air temperatures are shown in Fig. 13 (left, summer) and (right, winter). Generally, the air temperature doesn't vary much between the cases. However the rise of the $\mathrm{H} / \mathrm{W}$ ratio ends up in a decrease in maximum air temperature (at around $1.00 \mathrm{pm}$ ), but this decrease is extremely small $\left(<1^{\circ} \mathrm{C}\right.$ in summer and $<0.5^{\circ} \mathrm{C}$ in winter) [3] In the summer, the most decrease is achieved by using trees and better reflectivity of the pavements and roads.

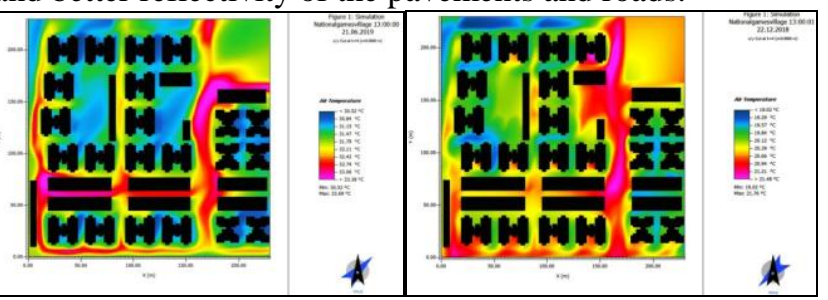

Fig. 13: Simulation results of air temperature (left) at $1.00 \mathrm{pm}$ the summer day (21 June) and (right) at $1.00 \mathrm{pm}$ the winter day (22 December) at a height of $900 \mathrm{~mm}$ from GL.

B. Outdoor Relative Humidity [3]

The simulated results of outdoor Relative Humidity are shown in Fig. 14 (left, summer) and (right, winter). Relative Humidity doesn't vary much between these cases. However the rise of the $\mathrm{H} / \mathrm{W}$ ratio results in a decrease in maximum relative humidity (at around $1.00 \mathrm{pm}$ ), but this decrease is small (1-2\% in summer and 3-4\% [3].

\section{Published By:} in winter) 


\section{Climatic Envelope as an Urban Planning Tool to Configure Urban Fabric of Guwahati City to Support Daylight and Natural Ventilation}

In the summer, maximum decrease is achieved along the wider pavements and wider roads with low $\mathrm{H} / \mathrm{W}$ ratio [3].
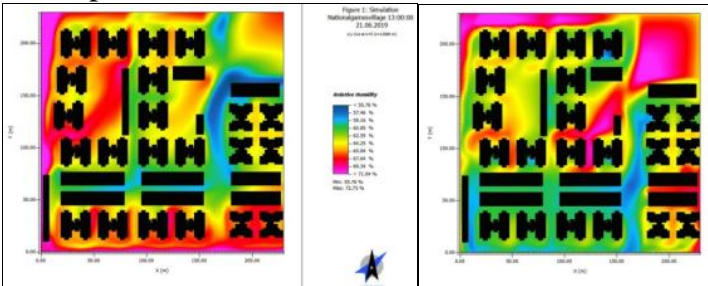

Fig. 14: Simulation results of relative humidity (left) at $1.00 \mathrm{pm}$ the summer day (21 June) and (right) at $1.00 \mathrm{pm}$ the winter day (22 December) at a height of $900 \mathrm{~mm}$ from GL. [3]

\section{Outdoor Wind Speed}

The simulated results of outdoor Wind velocity at various points inside the residential complex is shown in Fig. 15 (left, summer) and (right, winter). In summer, the air speed in neighbourhood arrangement of building blocks remains within $1.73 \mathrm{~m} / \mathrm{s}$ to $4.31 \mathrm{~m} / \mathrm{s}$ when $\mathrm{H} / \mathrm{W}$ ratio $<1$ and air speed is $5.15 \mathrm{~m} / \mathrm{s}$ when $\mathrm{H} / \mathrm{W}$ ratio $>1$ [3]. In winter, the air speed around the blocks varies between $1.30 \mathrm{~m} / \mathrm{s}$ to $3.30 \mathrm{~m} / \mathrm{s}$ where $\mathrm{H} / \mathrm{W}$ ratio $<1$ and air speed is $4.55 \mathrm{~m} / \mathrm{s}$ when $\mathrm{H} / \mathrm{W}$ ratio $>1$ [3]. In both summer and winter, rise in $\mathrm{H} / \mathrm{W}$ ratio leads to the rise in air speed.
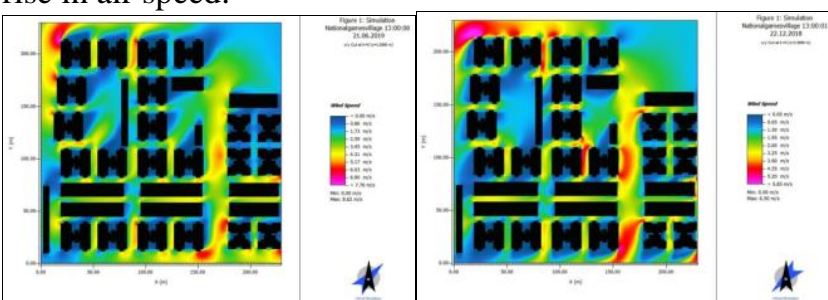

Fig. 15: Simulation results of wind velocity (left) at 1.00 pm the summer day (21 June) and (right) at $1.00 \mathbf{~ p m}$ the winter day (22 December) at a height of $900 \mathrm{~mm}$ from GL.

\section{Ventilation rate in typical residential apartment building of Guwahati}

In most of the apartments in Guwahati, natural ventilation is achieved by opening windows. Information on ventilation rates are required to calculate the thermal comfort and energy use of a building [3]. Average ventilation rate is calculated on the basis of external wind action hitting the building envelope within $45^{\circ}$ angles.

Ventilation rate because of prevailing regional wind is calculated by the following formula:

$$
\mathrm{Q}=\mathrm{KAV}
$$

Where,

$\mathrm{Q}=$ Rate of air flow in $\mathrm{m}^{3} / \mathrm{h}$;

$\mathrm{K}=$ Coefficient of effectiveness, which can be taken as 0.6 for wind perpendicular to openings and 0.3 for wind at an angle less than $45^{\circ}$ to the openings; [3]

$$
\begin{aligned}
& \mathrm{A}=\text { openable area of inlet in } \mathrm{m}^{2} \text {; and } \\
& \mathrm{v}=\text { Wind speed in } \mathrm{m} / \mathrm{h} \text {. }
\end{aligned}
$$

The average ventilation rate in winter and summer of various rooms of MIG dwelling units of national Games Village in Guwahati are shown in the table: 10. Typical MIG dwelling units with carpet area of $105 \mathrm{~m}^{2}$ at National games village is analysed for parametric studies. The apartment consists of a living/dining hall, a kitchen, two toilets and three bedrooms [3]. The dwelling unit is on the third floor and has three outside walls exposed to the outdoor climate [3]. The user pattern follows the typical cultural model of Assam, such as family size, user behaviour (opening and shutting of windows for ventilation) [3]

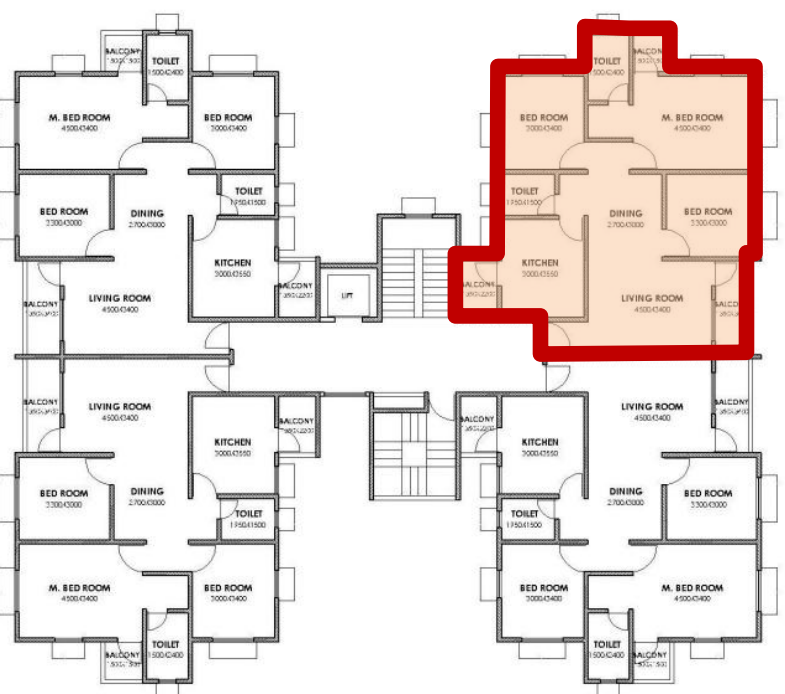

Fig: 16 typical 3BHK middle income group apartment of National Games Village, Guwahati [3]

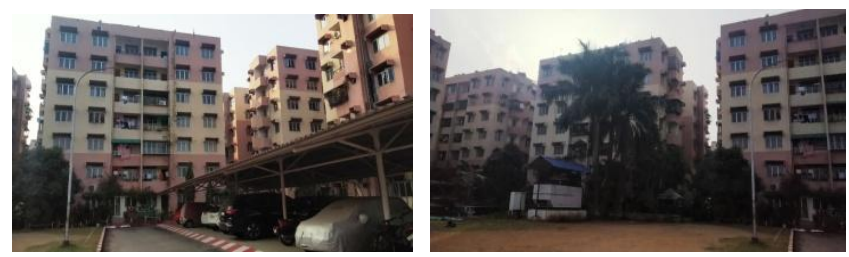

Fig: 17 Existing views of housing complex of national games village [3]

Table: 10 measured ventilation rate in the tested apartment in winter [3]

\begin{tabular}{|l|l|c|c|c|c|c|}
\hline \multicolumn{7}{|c|}{ National Games village residential neighbourhood } \\
\hline $\begin{array}{l}\text { Sr. } \\
\text { No }\end{array}$ & Room & $\begin{array}{l}\text { air } \\
\text { flow } \\
\text { rate } \\
\text { (ach) }\end{array}$ & $\begin{array}{c}\text { WFR }_{\text {op }} \\
(\%)\end{array}$ & $\begin{array}{l}\text { Rec. } \\
\text { Temp } \\
.\end{array}$ & $\begin{array}{c}\text { Desirabl } \\
\text { e Air } \\
\text { Change } \\
\text { rate }\end{array}$ & Remark \\
\hline 1 & $\begin{array}{l}\text { Living/ } \\
\text { Dining }\end{array}$ & $\begin{array}{c}6.30 \\
\pm 0.05\end{array}$ & $\begin{array}{c}14.96 \\
\%\end{array}$ & 23.4 & 3.0 & ok \\
\hline 2 & Kitchen & $\begin{array}{c}4.30 \\
\pm 0.05\end{array}$ & $\begin{array}{c}22.50 \\
\%\end{array}$ & 27.4 & 8.0 & Below \\
\hline 3 & $\begin{array}{l}\text { M. Bed } \\
\text { Room }\end{array}$ & $\begin{array}{c}7.96 \\
\pm 0.05\end{array}$ & $\begin{array}{c}28.76 \\
\%\end{array}$ & 24.1 & 2.0 & ok \\
\hline 4 & $\begin{array}{l}\text { Bed } \\
\text { Room 1 }\end{array}$ & $\begin{array}{c}4.86 \\
\pm 0.05\end{array}$ & $\begin{array}{c}26.47 \\
\%\end{array}$ & 25.3 & 2.0 & ok \\
\hline 5 & Bed & 3.24 & 18.18 & 25.1 & 2.0 & ok \\
& Room 2 & \pm 0.05 & $\%$ & & & Below \\
\hline 6 & Toilet 1 & 0.49 & $9.23 \%$ & 24.2 & 6.0 & \\
\hline 7 & Toilet 2 & 0.49 & $7.50 \%$ & 24.0 & 6.0 & Below \\
& & \pm 0.05 & & & & \\
\hline
\end{tabular}

The average measured ventilation rate in residential apartment in winter period varies from 1.85 ach to 4.68 ach \pm $14 \%$. The average ventilation rate is not similar to the ventilation rate of individual rooms (see Table: 10) of the tested apartment. Ventilation rate is a smaller amount than the desirable level in all rooms except bed rooms and living lounge.

Published By:

Blue Eyes Intelligence Engineering and Sciences Publication 
Average temperature difference between the inside and outside is approximately $10{ }^{\circ} \mathrm{C}$ (indoor average $+24.8{ }^{\circ} \mathrm{C}$ and outdoor average $+14.8^{\circ} \mathrm{C}$ ), the gentle wind speed $(3.0 \mathrm{~m} / \mathrm{s})$ [3], and also in reality, the windows are closed most of the time (apart from morning airing).

\section{RESULTS AND DISCUSSIONS}

In climatic envelope techniques, daylight spacing angle and solar elevation angle are conceptualised to regulate sky exposure angle by limiting street wall height and spacing between adjacent buildings. A comparative analysis of case study area is completed where; ground coverage is kept at $45 \%$ as per GMDA regulations for all the cases. $\mathrm{H} / \mathrm{W}$ ratio recommendations vary in between 1.26 to 2.16. Maximum Allowable Volumes (MAV) allowed varies from FAR 2.1 to FAR 3.15. The minimum density is determined by the solar envelope. Table: 11 show the comparative analysis of the $\mathrm{H} / \mathrm{W}$ ratio, Maximum allowable Volume (MAV) and FAR for different daylight planning tools.

Table 11: Comparative statement of $H / W$ ratio, FAR and Maximum Allowable Volume [2]

\begin{tabular}{|l|c|l|l|l|l|}
\hline $\begin{array}{l}\text { Planning } \\
\text { Tools }\end{array}$ & $\begin{array}{l}\text { H/W } \\
\text { ratio }\end{array}$ & MAV(Cum) & FAR & $\begin{array}{l}\text { Exposure } \\
\text { Plane } \\
\text { angle }\end{array}$ & Remark \\
\hline DSA & 1.56 & 9270.00 & 2.62 & $55^{\circ}$ & $\begin{array}{l}\text { Daylight reaches to ground } \\
\text { floor }\end{array}$ \\
\hline $\begin{array}{l}\text { Solar } \\
\text { Envelope } \\
\text { in 21 Dec. }\end{array}$ & 1.26 & 7470.00 & 2.10 & $22.71^{\circ}$ & $\begin{array}{l}\text { Daylight reaches to ground } \\
\text { floor and solar radiation } \\
\text { reaches to 2nd floor }\end{array}$ \\
\hline $\begin{array}{l}\text { Existing } \\
\text { GMDA } \\
\text { Setbacks }\end{array}$ & 2.16 & 11070.00 & 3.15 & $90^{\circ}$ & $\begin{array}{l}\text { No daylight reaches to first } \\
\text { floor and Solar radiation } \\
\text { reaches to 2nd floor }\end{array}$ \\
\hline
\end{tabular}

Fig: 18 show the comparative analysis of the building envelope recommended by various planning tools. The climatic envelope recommends an $\mathrm{H} / \mathrm{W}$ ratio of 1.26 while achieving a FAR of 2.10 which is more that the present GMDA permissible FAR of 1.75. The climatic envelope offer daylight access to Ground floor of adjacent building and permit solar access to the second floor of the adjacent building which is rather satisfactory in an urban spatial environment.

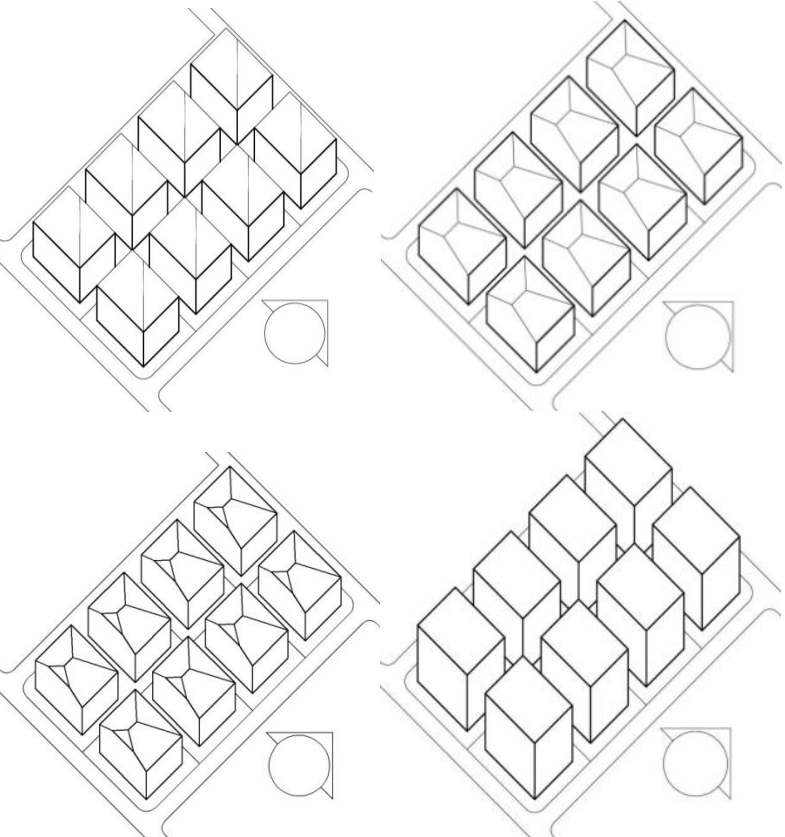

Fig.18 (a) Daylight spacing angle (b)Solar Envelope (c) Climatic Envelope (d) Existing Setback

\section{A. Technical Analysis and Discussions}

Fig. 19 Daylight factor in street canyon proportions [5]

The graph shown in Fig: 19 indicate that daylight factor (DF) is proportionate to $\mathrm{H} / \mathrm{W}$ ratio.

Results shown within the graph are valid in overcast sky conditions and as a result the variance of daylight distribution in diverse sky conditions in not a major factor. From the graph, it's observed that two major variables can influence DF and $\mathrm{H} / \mathrm{W}$ ratio relationships are:

1. Reflectance of outside wall

2. WFR of the outside wall of the reference room

Significant effect of urban canyon proportions on daylight levels can easily be referred from this graph. The daylight factor inside the building decreases with the rising $\mathrm{H} / \mathrm{W}$ ratios. Increase in window area affects increasing daylight factors. More increases crop up in lower $\mathrm{H} / \mathrm{W}$ ratios. The realistic upper limit of rising window area is about two-third of the area of the outside wall. Rising wall reflectivity incorporates a greater impact at higher $\mathrm{H} / \mathrm{W}$ ratios since a bigger percentage of interior illumination comes from reflected light. At low $\mathrm{H} / \mathrm{W}$ ratios, rising window area encompasses a much greater impact on raising DF than increasing wall reflectivity.

Using the graph, for an standard ambient light level of about $2.0 \%$ D.F, an H/W ratio of about 0.8 is required with low reflectance wall. This means for a city concerned with projecting daylight access to the lower floors of the building with a relationship such as:

For an typical DF $>1.5 \%$, keep $\mathrm{H} / \mathrm{W}$ ratios $<1.2$ with $33 \%$ of window area. While increased $\mathrm{WFR}_{\mathrm{op}}$ improves the indoor ventilation rate of the room area.

Typical ROW of Guwahati varies from $13.8 \mathrm{~m}$ to $24.0 \mathrm{~m}$ for residential streets. Collector and arterial streets ROW's are $24.0 \mathrm{~m}$ to $36.0 \mathrm{~m}$. Using the above relationship to safeguard daylight access and assuming a steady street wall height, the boundaries would apply for following height (story height = 3.0m).

Table 7: Comparison of allowable height in different right of way (ROW) [2, 3]

\begin{tabular}{|c|l|l|l|l|l|l|}
\hline ROW & $\begin{array}{l}\mathrm{H} / \mathrm{W} \\
\text { ratio }\end{array}$ & $\begin{array}{l}\text { Nos of } \\
\text { stories }\end{array}$ & $\begin{array}{l}\text { Minimum \% } \\
\text { of windows }\end{array}$ & $\begin{array}{l}\text { Minimum } \\
\mathrm{WFR}_{\text {op }}\end{array}$ & $\begin{array}{l}\text { Desirable } \\
\text { air change } \\
\text { rate }\end{array}$ & reflectance \\
\hline $13.8 \mathrm{~m}$ & 1.2 & $\begin{array}{l}5 \\
\text { storied }\end{array}$ & $33 \%$ & $16.66 \%$ & 2.0 & $\begin{array}{l}\text { low reflectance } \\
\text { wall }\end{array}$ \\
\hline $24.0 \mathrm{~m}$ & 1.2 & $\begin{array}{l}9 \\
\text { storied }\end{array}$ & $33 \%$ & $16.66 \%$ & 2.0 & $\begin{array}{l}\text { low reflectance } \\
\text { wall }\end{array}$ \\
\hline $36.0 \mathrm{~m}$ & 1.2 & $\begin{array}{l}14 \\
\text { storied }\end{array}$ & $33 \%$ & $16.66 \%$ & 2.0 & $\begin{array}{l}\text { low reflectance } \\
\text { wall }\end{array}$ \\
\hline
\end{tabular}

With the assistance of $\mathrm{H} / \mathrm{W}$ ratios establishing a maximum street wall height, a prescriptive climatic envelope is determined by sky exposure angle of DSA and SEA.

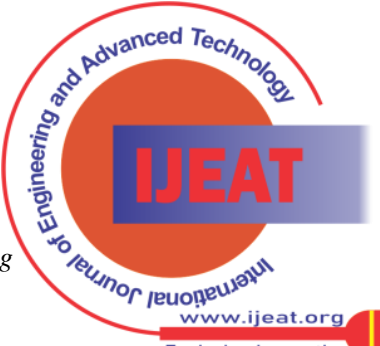




\section{Climatic Envelope as an Urban Planning Tool to Configure Urban Fabric of Guwahati City to Support Daylight and Natural Ventilation}

This method may be effectively employed to regulate planning measures like FAR, maximum building height and relative land use pattern for daylight access and natural ventilation.

\section{CONCLUSION}

This study also analyses the probabilities of constructing a climatic envelope by combining two commonest urban planning techniques of daylight spacing angle and solar elevation angle to produce daylight access, solar radiation and natural ventilation especially within the residential zone of Guwahati city. Daylight access controls are summarized, compared and analysed for density implications of GMDA regulations. It's been observed that every tool controls sky exposure plane by limiting street wall height or spacing between buildings. For north latitude of 26.11 in Guwahati, $\mathrm{H} / \mathrm{W}$ ratios vary between 1:2 to 2:1. Maximum allowable volume and maximum FAR for both planning tools are found out. The analysis of the graph shows a straightforward approximate relationship between street width to building height and therefore the daylight levels for lowest \% of window area. This rule will permit determining maximum street wall height for a given street width or to decide the side and rear setbacks of building for a preset building height.

This study concludes as follows:

1. The daylight factor decreases with rising $\mathrm{H} / \mathrm{W}$ ratios.

2. The normal DF and minimum DF increases in lower $\mathrm{H} / \mathrm{W}$ ratios. The realistic upper degree of increasing the window area is $2 / 3$ area of the outside wall area.

3. Rising reflectivity of the outside wall increases the inside $\mathrm{DF}$ and contains a greater impact on higher $\mathrm{H} / \mathrm{W}$ ratios.

4. Increasing window area increases the $\mathrm{WFR}_{\mathrm{op}}$ and includes a greater impact on the ventilation rate inside all habitable room.

This study concludes with an initiative that the climatic envelope may be used as preliminary urban planning tool to configure urban fabric of Guwahati city especially within the residential areas to support day lighting and natural ventilation. This study will help in framing GMDA building bye-laws incorporating energy-efficient principles in building design and also help to work out urban zoning controls for daylight access and street right-of-way (ROW).

\section{REFERENCES}

1. ASHRAE Standard 55, 1992, Thermal environmental conditions for human occupancy, ASHRAE Inc., Atlanta.

2. Barman A, Roy M, Dasgupta A, 2020, Study of daylight envelope as an urban planning tool in determining building height to street width $(\mathrm{H} / \mathrm{W})$ ratios in Residential Zone of Guwahati city, International Journal of Creative Research and Thoughts (IJCRT), pp. 4376-4383. (C) 2020 IJCRT | Volume 8, Issue 6 June 2020 | ISSN: 2320-2882

3. Barman A, Roy M, Dasgupta A, 2020, Thermal requirements of a residential apartment building through natural ventilation in the warm and humid climate of Guwahati , International Journal of Engineering Research and Technology (IJERT), pp. 1356-1363. (C) 2020 IJERT | Volume 9, Issue 6 June 2020 | ISSN: 2320-0181

4. Barman A, Roy M, Dasgupta A, 2020, Energy use in building envelope of a residential apartment building in the warm and humid climate of Guwahati, Assam - to be published by International Journal of Innovative Technology and Exploring Engineering (IJITEE), (C) 2020 IJITEE | Volume 9, Issue 11 September 2020 | ISSN: 2278-3075

5. Brown, G.Z and Dekay, M., "Sun, Wind and Light, Architectural Design Strategies, $2^{\text {nd }}$ Edition"

6. Bureau of Indian Standards (BIS). 2016. National Building Code of India 2016.

7. Eco-Niwas samhita 2018 (Energy Conservation Building Code for Residential Buildings) Part I: Building Envelope

8. Energy conservation building code 2017

9. GMDA Building Bye Laws 2014

10. Guwahati Master Plan 2025

11. Georgakis, G. and Santamouris, M. (2003) Urban Environment Research Report, URBVENT project, European Commission, Athens

12. Kaison online Calculator for solar elevation and Azimuth angle calculation

13. Knowles, R. 1981 "Sun, Rhythm, Form"

14. Model Building Bye laws 2016

15. Pandya Sujal V.,(2011), Tall buildings and urban microclimate - a bioclimatic study of urban fabric, People and Buildings MC2011 - A conference for Masters Students in sustainable buildings organised by NCEUB

16. Singh, M.K. and Mahapatra, S., 2005, Bio-climatic classification of North East India, International Seminar and Exhibition on Non-conventional and Renewable Energies, Energy Efficiency and Sustainability, "Prithvi 2005", 2026 Feb., Thiruvananthapuram, India.

17. White, R. 1988, "Daylight and Sunlight regulations for cities"

\section{AUTHORS PROFILE}

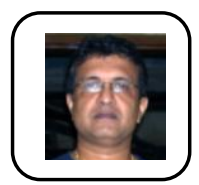

Amal Barman, graduated from Dept. of Architecture, Faculty of Technology \& Engineering, M.S. University of Baroda, Gujarat in 1992. Completed his M.Arch. from Aayojan school of Architecture, Jaipur in 2014 under YCMOU, Maharashtra. Presently pursuing Ph.D. in Architecture from Jadavpur University, Kolkata, India. Registered with Council of Architecture and a life member of Indian Institute of Architect. After graduation he started his professional career in Guwahati, Assam. In early years of his career, he studied various elements of vernacular architecture of Assam and used some of these vernacular elements in his design especially in residential buildings. Published 3 research papers and presented one conference paper in $53^{\text {rd }}$ international conference of ASA 2019 at IIT, Roorkee, India.

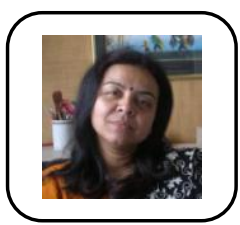

Dr. Madhumita Roy, graduated from Jadavpur University, Kolkata, West Bengal in 1991. Passed M.Arch. from Jadavpur University, Kolkata, West Bengal in 1997 and complted her Ph.D. in Architecture from Jadavpur University, Kolkata, India in 2004. Presently working as a Professor in Department of Architecture, Jadavpur University, and Kolkata, India. Registered with Council of Architecture, Dr. Roy started her professional career as an architect in Kolkata Municipal Corporation in 1994. After that she served for various organisations till she joined Jadavpur University. Her field of specialization is urban design, housing and energy efficiency in built environment. She published many research papers and presented number of conference papers in national and international conferences.

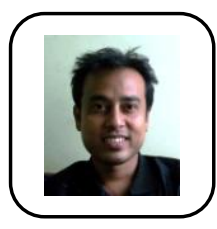

Dr. Arpan Dasgupta, graduated from A.B.I.T. Piloo Mody College of Architecture, Cuttok under Utkal University, Bhubaneswar, Urissa in 1997. Passed M.Arch. from Jadavpur University, Kolkata, West Bengal in 2003 and complted her Ph.D. in Architecture from Jadavpur University, Kolkata, India in 2016.Presently working as Associate Professor in Amity school of Architecture and Planning, Amity University, Kolkata, India. Registered with Council of Architecture. Dr. Roy started his career as a freelance architect after his post graduation till he joined Amity University as an associate professor. Published 22 research papers in various subjects and presented number of conference papers in national and international conferences.
Published By:

Blue Eyes Intelligence Engineering and Sciences Publication

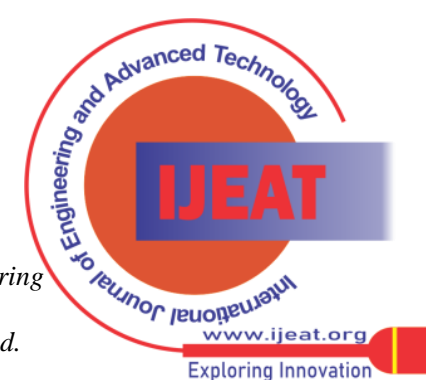

